\title{
Fraturas com arrancamento do anel apofisário ("limbus") póstero-superior da vértebra L5, associado com hérnia discal pré-marginal em atletas
}

Avulsion fractures of apophysial ring ("limbus") posterior superior of the $L 5$ vertebra, associated to pre-marginal hernia in athletes.

\section{Eduardo Barros Puertas ${ }^{1}$, Marcelo Wajchenberg ${ }^{2}$, Molsés Cohen ${ }^{3}$, Mario Néla ISoldi', Luciano Miller Reis Rodrigues 5 e Paulo Satiro de Souza ${ }^{5}$}

\section{RESUMO}

O aumento de adolescentes praticando esportes de forma cada vez mais competitiva tem causado o aumento de lesões relacionadas à prática desportiva. A dor lombar é uma queixa freqüente entre os atletas, geralmente relacionada a contraturas da musculatura paravertebral e fraturas ( espondilólise ) devido ao excesso de treinamento e aplicação de técnicas incorretas. Porém, outras etiologias podem causar a dor lombar, como processos infecciosos, tumorais e fraturas.

As fraturas com arrancamento do anel apofisário são lesões incomuns e raramente ocorrem na região póstero-superior da vértebra L5. Os relatos da literatura mostram que o local mais acometido é a região póstero-inferior da vértebra L4. Apresentamos dois casos de atletas jovens com esta incomum lesão. 0 objetivo deste trabalho é discutir a possível etiologia, os melhores métodos para o diagnóstico e possíveis formas de tratamento desta patologia.

Descritores: Fratura com arrancamento, anel apofisário, hérnia discal pré-marginal.

\section{INTRODUÇÃO}

A dor na região lombar é uma queixa freqüente dos atletas, porém na maioria das vezes o diagnóstico fornecido para o atleta é de lombalgia relacionada com contratura da musculatura paravertebral. A radiografia simples, na maioria das vezes, adiciona poucas informações ao examinador, porém alterações sutis podem justificar a necessidade de outros exames, como a tomografia computadorizada e a ressonância magnética. A espondilólise é a lesão óssea mais frequente na coluna vertebral lombar dos atletas, acometendo principalmente a vértebra L5, porém outras patologias são importantes no diagnóstico diferencial, como os processos infecciosos, tumorais e fraturas.

\section{SUMMARY}

The number of sport related injuries has raised as the increasing number of adolescents practicing competitive sports. Lumbar pain is a frequent complaint among young athletes. It is usually related to the contracture of paravertebral muscles and fractures (spondylolysis) caused by excessive practicing and incorrect techniques. However, other etiologies can cause lumbar pain, such as infectious processes, tumor and fractures.

Avulsion fractures of the apophysial ring are uncommon lesions which rarely happen in the posterior superior area of the $L 5$ vertebra. The literature shows that the most susceptible place to injuries is the posterior inferior area of the L4 vertebra. This paper presents two cases of young athletes with this unusual lesion. The objective of this work is to discuss the possible etiology and the best diagnostic and treatment procedures for this pathology.

Key words: Avulsion fractures of spine, spine lesions in athletes, apophysis ring lesions.

\section{INTRODUCTION}

Low back pain is a common complaint among athletes, however, most of the times, the diagnosis given to the athlete is of a back pain related to paravertebral muscles contraction. Plain radiographs, generally add few information to the examiner, however subtle local changes may justify the necessity of other exams, such as TC scan or MRI. Spondilolysis is the most frequent spinal bone injury in athletes, involving mainly L5, however other diseases are important as differential diagnosis, such as infections, tumors and fractures.

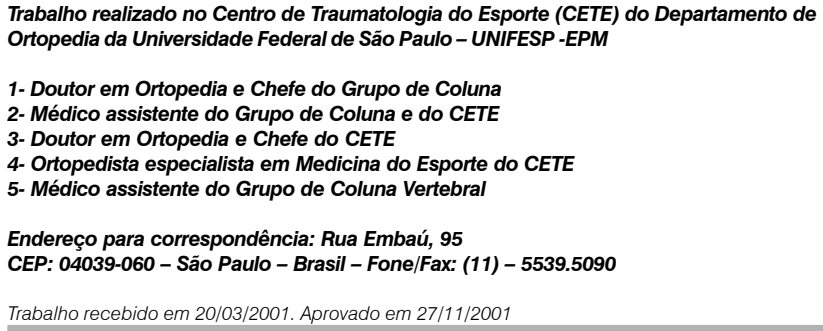

Work performed in the Centro de Traumatologia do Esporte (CETE) of the Departamento de Ortopedia da Universidade Federal de São Paulo - UNIFESP - EPM

1- PhD in Orthopaedics, Head of the Spine Group

2- Assistant doctor of the Spine Group and of the CETE

3- PhD in Ortopaedics and Head of the CETE

4- Orthopaedic Surgeon and Specialist in Sports Medicine by CETE

5- Assistant Doctor of the Spine Group

Address: Rua Embaú, 95

CEP: 04039-060 - São Paulo - Brasil - Fone/Fax: 11 - 5539.5090 
As fraturas com arrancamento posterior do anel apofisário são raras $^{(4)}$, com poucos relatos na literatura. O primeiro relato desta patologia foi realizado por Lowrey(8) em 1973, com o tratamento cirúrgico de um adolescente com ciatalgia, causada por compressão radicular. O local mais acometido por esta lesão é a região posterior do planalto inferior da vértebra de $L 4^{(6,7)}$. Apresentamos dois casos de atletas, sendo um jogador de futebol e um praticante de levantamento de peso, com fratura em arrancamento do anel apofisário póstero-superior da vértebra L5, associado à hérnia discal pré-marginal.

\section{CASUÍSTICA E MÉTODOS}

\section{Caso 1}

A.L.D.T., 17 anos, do sexo masculino, praticante de levantamento de peso, realizava treinamentos diários (5 vezes por semana). Procurou atendimento médico referindo dor lombar há 2 meses, com intensificação dos sintomas e incapacidade funcional após realizar exercício de agachamento com carga excessiva. O paciente não referia qualquer sintoma irradiado para os membros inferiores Ao exame físico inicial, notava-se intenso espasmo da musculatura lombosacra, com encurtamento da musculatura isquiotibial e relativa fla-

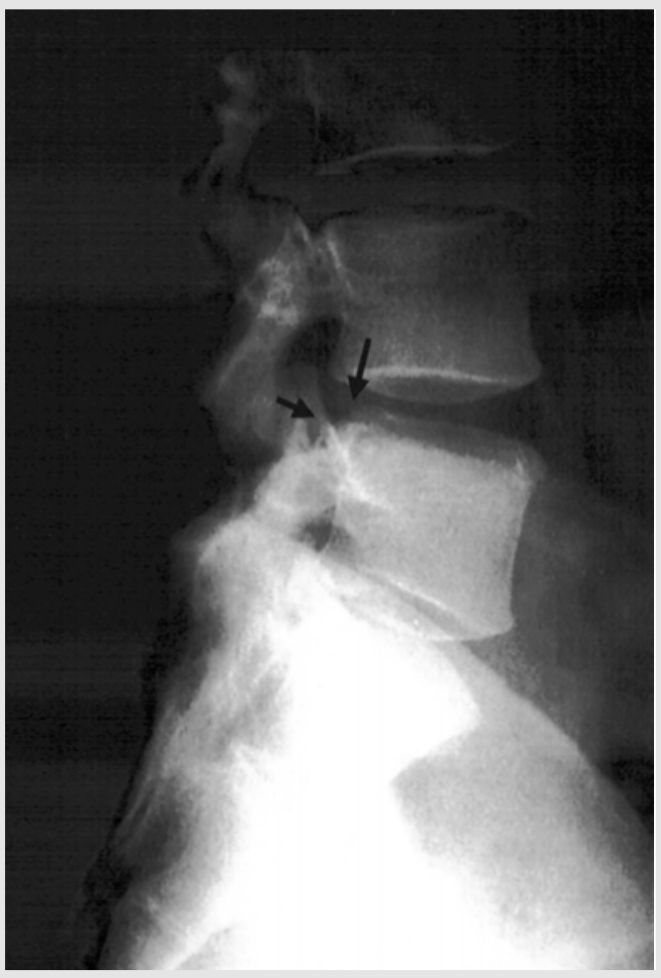

Figura 1 - Exame radiográfico em perfil de coluna lombosacra mostrando deslocamento posterior de pequeno fragmento ósseo do planalto superior da vértebra $L 5$.

Figure 1 - Lumbo sacral spine radiograph displaying small posterior displacement of a small bone fragment from superior bone plateau of $L 5$ vertebra.
Avulsion fractures of the posterior part of apophysial ring are rare (4), with few reports in literature. The first report of this pathology was made by Lowrey ${ }^{(8)}$ in 1973, with a surgical treatment of a teenager presenting sciatalgia, caused by radicular compression. The most frequently involved place is the posterior region of the inferior plateau of the $L 4$ vertebra $^{(6,7)}$. We present the cases of two athletes, one soccer player and one weight lifter, with avulsion fracture of the posterior superior apophysial ring of $L 5$ vertebra, associated to a pre-marginal disc herniation.

\section{CASES AND METHODS}

\section{Case 1}

A.L.D.T., 17 years old, male, weight lifter, practiced daily (5 days/ week). Came for medical assistance reporting lumbar pain for 2 months, with worsening of the symptoms and incapacity after crouching with excessive load. The patient did not report any symptom of irradiation to lower limbs. At initial physical examination, it was noticed intensive contracture of lumbosacral muscles, shortening of ischiotibial muscles and a relative relaxation of abdominal muscles. No neurologic change was found. Radiographic examinaticidez da musculatura abdominal. Não havia qualquer alteração do exame neurológico. O exame radiográfico evidenciou fratura, com deslocamento posterior de pequeno fragmento ósseo do planalto superior da vértebra L5. Tal fragmento pôde ser melhor visibilizado através da tomografia computadorizada . Neste exame evidenciou-se também hérnia discal centro lateral esquerda.

O paciente foi tratado com medicação analgésica e antiinflamatória, uso de órtese lombar, reabilitação fisioterápica e afastamento da sua atividade física durante três meses. Após este período houve completa melhora dos sintomas e retomada progressiva do treinamento, estando assintomático há 7 meses.

\section{Caso 2}

B.C.L., 22 anos, do sexo masculino, jogador de futebol, procurou atendimento médico referindo dor lombar com intensa ciatalgia irradiada para o membro inferior esquerdo, com incapacidade para a prática esportiva. O atleta permaneceu com os sintomas por dois meses até procurar o nosso serviço. Ao exame físico notava-se intenso espasmo da musculatura paravertebral on displayed a fracture, with a posterior displacement of a small bone fragment of superior plateau of $L 5$ vertebra. This fragment could be better seen through a CT scan. In this examination, a left central lateral disc herniation was also identified.

The patient was treated with analgesics and NSAIDs, use of a lumbar orthesis, physiotherapeutic rehabilitation and rest of his physical activities for three months. After this period, complete relief of the symptoms was observed, and the patient allowed to a progressive return to his activities. He had no symptoms for 7 months.

\section{Case 2}

B.C.L., 22 years old, male, soccer player, came for medical assistance reporting severe lumbar pain with a severe sciatalgia irradiated to left lower limb with incapacity for practicing sport. The athlete remained with the symptoms for two months, until coming to our service. At physical examination a severe spasm of paravertebral lumbosacral muscles was 
lombosacra, com encurtamento da musculatura isquiotibial. A manobra de Lasègue era positiva quando realizada no membro inferior esquerdo, notando-se discreta hipotrofia da musculatura quadriciptal e diminuição do reflexo patelar à esquerda. As radiografias realizadas não demonstravam, com clareza, alterações ósseas. A tomografia óssea permitiu a visibilização de fragmento ósseo, avulsionado do planalto superior da vértebra L5, deslocado posteriormente, em direção ao forâmen de conjugação esquerdo. O fragmento ósseo estava consolidado na parede posterior da vértebra de L5, notandose também área de esclerose na região da avulsão A imagem sagital (reconstrução) permitiu a perfeita localização da lesão óssea. A ressonância magnética possibilitou a visibilização do disco intervertebral L4-L5, que apresentava sinais de degeneração e desidratação em imagens sagitais ponderadas em T2, além de volumosa hérnia discal centro lateral esquerda, com compressão radicular à esquerda.

O paciente foi tratado com medicação analgésica e antiinflamatória esteróide, órtese lombar, fisioterapia e repouso durante dois meses, sem que houvesse qualquer sinal clínico de melhora, notando-se aumento da apreensão e ansiedade do atleta. Foi indicada cirurgia para ressecção da hérnia discal, através de laminotomia unilateral, do lado esquerdo, realizando a curetagem do fragmento ósseo e foraminectomia, além da ressecção da hérnia discal. A cirurgia foi realizada sem intercorrências. O paciente teve alta hospitalar 24 horas após o ato cirúrgico, realizando sessões de hidroterapia a partir do quarto dia após a cirurgia. Durante o primeiro mês após a realização do tratamento cirúrgico o paciente permaneceu assintomático, apresentando somente sinais de en-

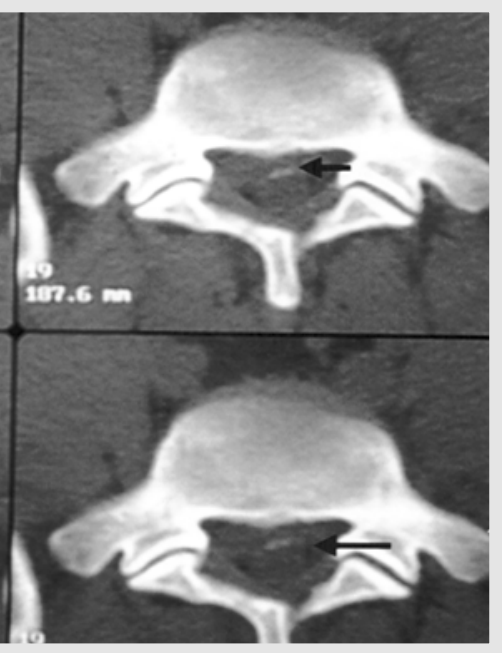

Figura 2 - Tomografia computadorizada, janela óssea mostrando fragmento ósseo dentro do canal vertebral.

Figure 2 - CT scan, bone window, displaying the bone fragment inside vertebral canal.

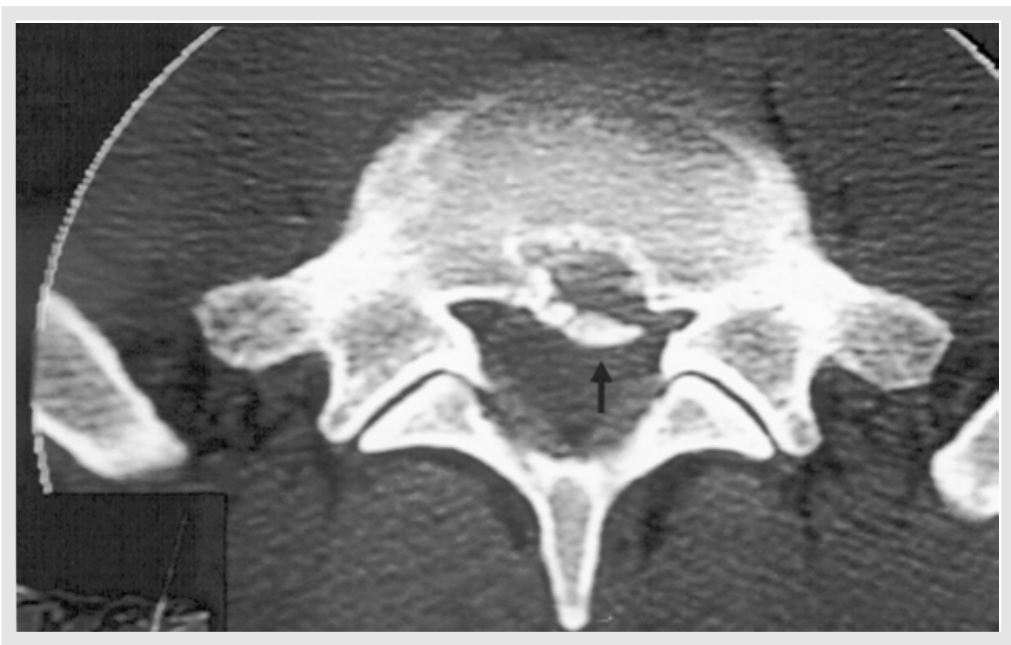

Figura 3 - Tomografia computadorizada, janela para partes moles, mostrando fragmento ósseo avulsionado do planalto superior da vértebra $L 5$ deslocado posteriormente em direção ao forâmen de conjugação esquerdo.

Figure 3 - CT scan, soft tissue window, displaying bone fragment avulsed from superior plateau of L5 vertebra, with posterior displacement towards left conjugation foramen. noticed, with shortening of ischiotibial muscles. Lasègue maneuver was positive in left lower limb, and a slight hypotrophy of quadriceps with reduction of left patellar reflex was also noticed. Radiographs didn't show clearly any bone change. CT scan allowed seeing a bone fragment avulsed from upper plateau of $L 5$ vertebra, posteriorly displaced trending to the left conjugation hole. The bone fragment was healed to the posterior wall of the $L 5$ vertebra, and sclerosis could be noticed at the avulsion site as well. Sagital image (reconstruction) allowed a perfect localization of the bone injury. MRI allowed identification of the L4-L5 intervertebral disc, which presented signs of degeneration and dehidratation in sagital images weighted in T2, besides a voluminous left central lateral disc herniation, with root compression to left.

The patient was treated with analgesics and steroid anti-inflammatory, lumbar orthesis, physiotherapy and rest during two months, without any clinical sign of improvement, with increasing apprehension and anxiety. Surgery was indicated for hernia resection through a unilateral left laminectomy, with curettage of the bone fragment and foraminectomy besides disc herniation resection. The proposed surgery was performed without problems. The patient was discharge from the hospital 24 hours after the surgery, being submitted to hydrotherapy starting the fourth day after the surgery. During the first month after performing the surgery the patient remained without symptoms, with only shortening of ischiotibial muscles. He returned to play soccer competitively by the end of the third treatment month. 
curtamento da musculatura isquiotibial. O atleta tornou a jogar futebol, competitivamente, no final do terceiro mês de tratamento.

\section{DISCUSSÃO}

A fratura com arrancamento do anel apofisário é uma patologia de difícil diagnóstico e com poucos relatos na literatura ${ }^{(1,4,5,6,7,8)}$. O local mais acometido, segundo vários autores, é a região póstero-inferior da vértebra $L 4^{(1,3,5,6,7,8)}$.Apresentamos, através do relato de dois casos, a presença desta lesão na região póstero-superior da vértebra L5, em atletas, um jogador de futebol e um praticante de levantamento de peso.

Entre as localizações incomuns desta lesão é importante mostrar através do relato de um caso ocorrido com um jogador de futebol que teve um deslocamento posterior do anel apofisário no planalto superior da vértebra S1, causando intensa lombociatalgia, devido à compressão da raiz de S1 à esquerda ${ }^{(3)}$.

Descreve-se, através do relato de um caso, o mecanismo de lesão em um adolescente, que praticava levantamento de peso, ressaltando a importância do movimento de flexão forçada associada à compressão axial(7), na etiologia da avulsão de fragmento da margem póstero-inferior do corpo vertebral da vértebra L4. Em outro caso houve o aparecimento de uma espícula óssea no planalto inferior da vértebra de L3, em uma ginasta de 14 anos de idade, ressaltando a associação entre a prática esportiva e a fratura apofisária nas vértebras lombares ${ }^{(5)}$

Vários termos foram utilizados para classificar esta lesão, como persistência epifisária, osso límbico, avulsão óssea posterior e nódulo cartilagíneo intra-ósseo póstero-marginal lombar ${ }^{(6)}$. Sugeriram o nome de defeito paradiscal, enfatizando a presença da hérnia discal primariamente, causando de forma secundária o arrancamento do fragmento ósseo(4) Observamos a presença de hérnia discal nos dois casos apresentados, estando sintomática em um dos pacientes. Acreditamos que a hérnia discal tem papel primário na fisiopatologia da fratura por arrancamento do anel apofisário.

Para explicar a fisiopatologia da lesão entendemos que microtraumas repetitivos, em atletas jovens, principalmente através de flexão e extensão abrupta e o carregamento de peso ${ }^{(9)}$, poderiam desencadear lesões da cartilagem epifisária e sobrecarga do disco intervertebral. O disco intervertebral do adolescente e adulto

\section{DISCUSSION}

Avulsion fracture of apophysial ring is difficult to diagnosis and has few reports in literature ${ }^{(1,4,5,6,7,8)}$. According to several authors, the most commonly affected place is the posterior inferior region of $L 4$ vertebra $^{(1,3,5,6,7,8)}$. We present in this report of two cases the presence of this injury in the posterior superior region of $L 5$ vertebra in athletes, one soccer player and one weight lifter.

Among the uncommon locations of this injury, it is important to say about the report of one case involving a soccer player who had a posterior displacement of the apophysis ring in the upper plateau of $S 1$ vertebra, causing severe lumbosciatalgia due to compression of the S1 left root ${ }^{(3)}$.

It is described through the report of one case, the mechanism of injury in a teenager who practiced weight lifting, stressing the importance of forced flexion associated with axial compression ${ }^{(7)}$, in the etiology of the avulsion of the fragment of the posterior inferior margin of the body of L4 vertebra. In another case, happened the appearance of a bony elevation in the inferior plateau of the L3 vertebra in a 14 years old gymnastic practitioner, stressing the link between sports practicing and apophysial fracture in lumbar vertebrae ${ }^{(5)}$.

Several terms were use to classify this injury, as epiphyseal persistence, limbic bone, posterior bone avulsion and intraosseous posterior marginal cartilage lumbar node ${ }^{(6)}$.

It was suggested the name paradiscal defect, emphasizing the presence of the discal herniation primarily, causing a secondary form, the avulsion of the bone fragment ${ }^{(4)}$. We observed the presence of disc herniation in both presented cases, being symptomatic in one patient. We believe that the discal herniation has a primary role in the physiopathology of the avulsion fracture of apophysial ring.

To explain the physiopathology of this injury, we understand that repeated micro traumatisms in young athletes, mostly through abrupt flexion and extension, and weight bearing ${ }^{(9)}$, could start injuries of epiphyseal cartilage and overload of intervertebral disc.

The intervertebral disc of the teenager and young adult has an increased turgor due to hydratation and the presence of polysacharides in the pulpous nucleus ${ }^{(6)}$. This nucleus exerts an increased pressure over the fibrous annulus, circunferencially and 
jovem tem um turgor aumentado, devido à hidratação e presença de polisacárides no núcleo pulposo(6). Este núcleo exerce maior pressão sobre o ânulo fibroso, circunferencialmente e sobre as placas terminais, cranial e caudalmente. O ânulo fibroso é aderido ao planalto vertebral superior e inferior através das fibras de Sharpey e algumas fibras do ligamento longitudinal posterior . $O$ aumento da pressão do núcleo pulposo sobre o ânulo fibroso pode desencadear a hérnia discal e a avulsão do fragmento ósseo da placa terminal. Houve o relato deste mecanismo através de ilustração(6).

A ossificação da cartilagem da placa terminal vertebral (anel apofisário ) inicia-se ao redor dos 5 anos tendo sua ossificação completa por volta dos 18 anos de idade ${ }^{(1,9)}$, podendo em alguns indivíduos persistir até os 25 anos ${ }^{(4)}$. Alguns autores sugerem que defeitos na ossificação do anel apofisário, como descrito na doença de Schmorl, estariam relacionados com esta patologia( ${ }^{(9)}$.

O diagnóstico desta patologia é difícil, pois a história clínica e o exame físico podem conduzir aos diagnósticos de lombalgia muscular e hérnia discal, devido a presença de ciatalgia. As radiografias simples podem demonstrar alterações sutis e não auxiliar o diagnóstico. A tomografia computadorizada permite excelente visibilização do fragmento ósseo ${ }^{(9)}$ avulsionado do planalto vertebral, principalmente através da reconstrução bidimensional. Porém este exame não permite a perfeita visibilização de hérnia discal e dos tecidos neurais. A ressonância magnética permite a avaliação do tecido cartilagíneo, discal e do grau de compressão das raízes nervosas, possibilitando adequado planejamento cirúrgico quando necessário ${ }^{(9)}$.

O tratamento desta patologia, está relacionado com o grau de compressão do tecido neural e da resposta ao tratamento incruento $O$ tratamento cirúrgico deve ser realizado quando o tratamento incruento for inefetivo(3) durante várias semanas. O tratamento cirúrgico consiste na realização de ampla laminectomia (bilateralmente), com discectomia e remoção do fragmento ósseo fraturado(2). Acreditamos que pode ser realizada laminotomia somente no lado da compressão radicular preservando as articulações facetárias para evitar instabilidades, conforme realizado no caso 2. A liberação da raiz comprimida e a foraminectomia podem ser realizadas através de pequena incisão, com mínima lesão da estrutura ligamentar e muscular, utilizando os recursos do microscópio, através de técnica mínima invasiva. Este procedimento é muito importante para atletas, que necessitam retornar as suas atividades físicas o mais rápido possível.

Durante o tratamento dos atletas é importante a abordagem multiprofissional, com integração entre o médico, fisioterapeuta, over the terminal plates, both cranial as caudally. The fibrous annulus is adhered to the upper and inferior vertebral plateau through the Sharpey fibers and some fibers of the longitudinal posterior ligament. The increase of the pressure by the pulpous nucleus over the fibrous annulus may lead to a discal herniation and the avulsion of the bone fragment from the terminal plate. There was the report of this mechanism through an illustration ${ }^{(6)}$.

The ossification of the vertebral terminal plate cartilage (apophysial ring) starts around the age of 5 years, being its ossification completed around the age of 18 years ${ }^{(1,9)}$, being possible in some individuals to persist up to the age of 25 years $^{(4)}$. Some authors suggest that ossification defects of the apophysial ring, as those described in Schmorl's disease, could be associated to this pathology ${ }^{(9)}$.

The diagnosis of this pathology is difficult, since the clinical history and physical examination can lead to a diagnosis of muscular back pain and discal herniation, due to the presence of sciatalgia. Plain radiographs may demonstrate subtle changes and do not help the diagnosis. CT scan allows an excellent evaluation of the avulsed bone fragment ${ }^{(9)}$, mainly through the bi-dimensional reconstruction. However, this exam doesn't allow a perfect evaluation of the discal herniation and of the neural tissues. MRI allows the evaluation of the cartilaginous tissue, of the disc and degree of compression of nerve roots, allowing an adequate planning of the surgery, when necessary ${ }^{(9)}$.

The treatment of this disease is related to the degree of neural tissue compression and reaction to conservative measures. Surgical treatment should be performed when conservative measures are ineffective ${ }^{(3)}$ after several weeks. Surgical treatment consists in performing wide laminectomy (bilaterally) with discectomy and removal of the bone fragment ${ }^{(2)}$. We believe that a laminectomy can be performed only on the affected side preserving the facetary joints thus avoiding instability, as performed in Case 2. Release of the compressed root can be performed through a small incision, with minimal damage to ligamental and muscular structure, using a microscope through a minimally invasive technique. This procedure is very important for athletes, who need to resume their physical activities as soon as possible.

During treatment of the athletes it is important to have a multi professional approach, involving doctor, physiotherapist, coacher, sponsor, being necessary a psychological support since being out of activity may bring economic, social and emotional conflicts. 
preparador físico, patrocinadores, sendo necessário um aporte psicológico, pois o afastamento da atividade esportiva pode gerar conflitos de ordem econômica, social e emocional.

\section{CONCLUSÕES}

A fratura com arrancamento do anel apofisário é uma patologia incomum e raramente acomete o planalto póstero-superior da vértebra L5, conforme relatado em nosso trabalho. A fratura do anel apofisário tem estreita relação com microtraumatismos repetitivos que ocorrem durante a prática desportiva. A lesão descrita através do relato de dois casos está associada à presença de hérnia discal marginal em pacientes adolescentes e adultos jovens.

A fratura com arrancamento do anel apofisário é uma patologia que deve ser sempre considerada no diagnóstico diferencial das lombalgias e lombociatalgias em atletas. A história clínica e o exame físico são inconclusivos, sendo necessários exames subsidiários para o diagnóstico da lesão. A tomografia computadorizada permite a visibilização do fragmento ósseo avulsionado e a ressonância magnética permite visibilizar o disco intervertebral e estruturas nervosas.

O tratamento desta lesão depende do quadro clínico do paciente e da resposta ao tratamento clínico, sendo importante a abordagem multiprofissional, considerando as peculiaridades e os anseios dos atletas.

\section{CONCLUSIONS}

Avulsion fracture of the apophysial ring is an uncommon disease, and rarely involves the posterior superior plateau of L5 vertebra, according to the reported in this paper. This injury has a close relationship to repeated micro traumatisms occurring during sport practice. The injury described through report of two cases is related to marginal disc herniation in teenagers and young adults.

Avulsion fracture of apophysial ring is a pathology that should be always considered in differential diagnosis of back pain and sciatalgia in athletes. Clinical history and physical examination are inconclusive, being necessary complementary exams for diagnosis. CT allows identifying the avulsed bone fragment and MRI to study the intervertebral disc and nervous structures.

Treatment of this injury is dependent of patients clinical picture and reaction to conservative treatment, being important a multi professional approach taking into consideration peculiarities and anxieties of the athlete.

\section{REFERÊNCIAS BIBLIOGRÁFICAS}

1. Dake M.D., Jacobs R.P., Margolin F.R.: Computed tomography of posterior lumbar apophysearing fractures. J. Comp. Assisted Tomog.1985; 9(4): 730-2.

2. Ehni G., Schneider S.J.: Posterior lumbar vertebral rim fracture and associated disc protusion in adolescence. J. Neurosurg. 1988; 68: 912-6.

3. Fujita K., Shinmei M., Hashimoto K., Shimomura Y.; Posterior dislocation of the sacral apophyseal ring. Am. J. Sports Medicine 1986; 14(3): 243-5.

4. Goldman A.B., Ghelman B., Doherty J.: Posterior limbus vertebrae: a cause of radiating back pain in adolescents and young adults. Skeletal Radiol. 1990; 19: 501-7.
5. Handel S.F., Twiford T.W.J., Reigel D.H., Kaufman H.H.: Posterior lumbar apophyseal fractures. Radiology 1979; 130: 629-.33.

6. Laredo J.D., Bard M., Chretien J., Kahn M.F.: Lumbar posterior marginal intra-osseus cartilaginous node. Skeletal Radiol. 1986; 15: 201-8.

7. Lippitt AB.: Fracture of vertebral body end plate and disk protusion causing subarachnoid block in na adolescent. Clin. Orthop. Relat. Resear.1976; 116: 112-5.

8. Lowrey J.J.: Dislocated lumbar vertebral epiphysis in adolescent children. Report of three cases. J. Neurosurg. 1973; 38: 232.

9. Rothfus W.E., Goldberg A.L., Deeb Z.L., Daffner R.H.: MR recognition of posterior lumbar vertebral ring fracture. J. Comp. Assist. Tomog. 1990; 14(5): 790-4 